University of Nebraska - Lincoln

DigitalCommons@University of Nebraska - Lincoln

Faculty Papers and Publications in Animal

Science

Animal Science Department

$1-1-1993$

\title{
Yearling Bulls Shorten the Duration of Postpartum Anestrus in Beef Cows to the Same Extent as Do Mature Bulls
}

Andrea S. Cupp

University of Nebraska-Lincoln, acupp2@unl.edu

M. S. Roberson

University of lowa, msr14@cornell.edu

T. T. Stumpf

University of Missouri, Columbia

M. W. Wolfe

Case Western University, mwolfe2@kumc.edu

L. A. Werth

University of Nebraska-Lincoln

See next page for additional authors

Follow this and additional works at: https://digitalcommons.unl.edu/animalscifacpub

Part of the Animal Sciences Commons

Cupp, Andrea S.; Roberson, M. S.; Stumpf, T. T.; Wolfe, M. W.; Werth, L. A.; Kojima, N.; Kittok, Roger J.; and Kinder, J. E., "Yearling Bulls Shorten the Duration of Postpartum Anestrus in Beef Cows to the Same Extent as Do Mature Bulls" (1993). Faculty Papers and Publications in Animal Science. 165.

https://digitalcommons.unl.edu/animalscifacpub/165

This Article is brought to you for free and open access by the Animal Science Department at DigitalCommons@University of Nebraska - Lincoln. It has been accepted for inclusion in Faculty Papers and Publications in Animal Science by an authorized administrator of DigitalCommons@University of Nebraska - Lincoln. 
Authors

Andrea S. Cupp, M. S. Roberson, T. T. Stumpf, M. W. Wolfe, L. A. Werth, N. Kojima, Roger J. Kittok, and J. E. Kinder 


\title{
Yearling Bulls Shorten the Duration of Postpartum Anestrus in Beef Cows to the Same Extent as Do Mature Bulls ${ }^{1}$
}

\author{
A. S. Cupp, M. S. Roberson ${ }^{2}$, T. T. Stumpf ${ }^{3}$, M. W. Wolfe ${ }^{4}$ L. A. Werth, \\ N. Kojima, R. J. Kittok, and J. E. Kinder 5
}

Department of Animal Science, University of Nebraska, Lincoln 68583-0908

\begin{abstract}
The objective of this study was to determine whether yearling bulls, when pastured with cows, reduced the duration of postpartum anestrus to the same extent as did mature bulls. This experiment was conducted over a 3-yr period. Cows were stratified by parity group to achieve $37 \%$ 2-yr-old and $63 \%$ mature ( $>2$-yr-old) cows within each treatment group (approximately 50 cows per treatment per year). Cows were assigned in the order in which they calved to one of three treatment groups: 1) isolated from bulls (NBE; $\mathrm{n}=158) ; 2$ ) exposed to mature bulls that were $>3 \mathrm{yr}$ of age (MBE; $n=154)$; or 3 ) exposed to bulls that were 1 yr of age (YBE; $n=152$ ). Beginning the 2nd wh after calving, cows were pastured with either sterile bulls that were $1 \mathrm{yr}(\mathrm{YBE})$ or $>3 \mathrm{yr}$ of age (MBE) (three bulls per treatment group). Blood
\end{abstract}

samples were collected twice weekly from late March until mid-July each year. Cows with serum concentrations of progesterone $>1 \mathrm{ng} / \mathrm{mL}$ for two consecutive sampling periods were assumed to have initiated estrous cycles after calving. Duration of postpartum anestrus in cows exposed to yearling bulls (YBE $=$ $61.8 \pm 1.8 \mathrm{~d})$ did not differ $(P>.10)$ from duration of postpartum anestrus in cows exposed to mature bulls $(\mathrm{MBE}=59.5 \pm 1.7 \mathrm{~d})$. Duration of postpartum anestrus was shorter $(P<.01)$ for cows exposed to bulls $(\mathrm{MBE}+\mathrm{YBE}=61.0 \pm 1.7 \mathrm{~d})$ than for cows isolated from bulls $(\mathrm{NBE}=72.3 \pm 1.8 \mathrm{~d})$. Therefore, the biostimulatory effect of bulls on the duration of postpartum anestrus in beef cows is independent of the age of bulls after they have reached $1 \mathrm{yr}$ of age.

Key Words: Postpartum Interval, Anestrus, Bull Exposure

J. Anim. Sci. 1993. 71:306-309

\section{Introduction}

Pasturing of multiparous and primiparous cows with bulls after calving shortens the duration of postpartum anestrus (Zalesky et al., 1984; Alberio et al., 1987; Naasz and Miller, 1987; Gifford et al., 1989; Custer et al., 1990; Burns and Spitzer, 1992).

\footnotetext{
${ }^{1}$ This research is published as paper no. 9946, Journal Series Nebraska Agric. Res. Div. The authors thank Laura Rife for assistance in preparation of this manuscript, Kenneth Pearson and Georgette Caddy for technical assistance with hormone analysis, and Karl Moline, Jeff Bergman, and Bob Broweleit for assistance with animal care.

${ }^{2}$ Present address: Dept. of Physiol. and Biophysics, Univ. of Iowa, Iowa City.

${ }^{3}$ Present address: Dept. of Anim. Sci., Univ. of Missouri, Columbia.

${ }^{4}$ Present address: Dept. of Pharmacol., Case Western Reserve Univ., Cleveland, $\mathrm{OH}$.

5 To whom correspondence should be addressed: A224j Anim. Sci., Univ. of Nebraska, Lincoln 68583-0908.

Received April 30, 1992.

Accepted October 1, 1992.
}

Shortening the duration of postpartum anestrus with biostimulation by bulls may decrease calving interval and increase herd productivity. Because primiparous cows tend to have longer postpartum anestrus, exposure of primiparous cows to bulls immediately after calving reduced postpartum anestrus to a greater degree than did exposure of multiparous cows (Gifford et al., 1989).

Age of the boar has been determined to have an effect on inducing onset of puberty in gilts (Kirkwood and Hughes, 1981). Gilts exposed to either 2-yr-old or 11-mo-old boars attained puberty $24 \mathrm{~d}$ earlier than gilts exposed to boars that were 6.5 mo of age. Thus, in the pig the biostimulation of gilts by boars of different ages has differential effects on induction of estrous cycles in anestrous gilts.

Although the effect of biostimulation by mature bulls on the duration of postpartum anestrus is well documented, the effect of younger bulls has not been evaluated. Therefore, we designed an experiment to address whether age of bull to which cows are exposed after calving affects the duration of postpartum anestrus. Our hypothesis was that the postpartum 
anestrus interval would be longer in cows exposed to 1 -yr-old bulls than in cows exposed to mature (3- to 4-yr-old) bulls.

\section{Materials and Methods}

Multiparous and primiparous cows (1/4 Angus, 1/4 Hereford, 1/4 Pinzgauer, 1/4 Red Poll; $n=464$ ) from the beef physiology herd located at the University of Nebraska Agricultural Research and Development Center were used during a 3-yr period (1987 through 1989). Each year, cows were stratified by parity group, $37 \%$ 2-yr-old and $63 \%$ mature cows (> 2 -yr-old), and assigned in the order in which they calved to one of three treatments: 1) isolated from bulls ( NBE, $\mathbf{n}=158$ ); 2) pastured with sterile, mature bulls ( MBE, $\mathbf{n}=154$ ); or 3) pastured with sterile, yearling bulls ( YBE, $\mathrm{n}=152$ ). Although care was taken to prevent cows from receiving the same treatment each year, two cows were inadvertently assigned to the same treatment group all $3 \mathrm{yr}$ and eight cows were in the same treatment group for two consecutive years.

Mature bulls used in this study were 3 to $4 \mathrm{yr}$ of age. The cows and their calves were moved to pastures during the 2nd wh after calving. Cattle were moved during the 2nd wk rather than immediately after calving to facilitate calf acceptance and grouping of animals for transport. Cows in the YBE and MBE groups were placed in pastures with sterile bulls that were $1 \mathrm{yr}$ (YBE) or $>3 \mathrm{yr}$ of age (MBE). Three bulls were used per treatment group. The sterile bulls remained with cows for approximately 9 wk until initiation of the breeding season. Sterile bulls were replaced with intact bulls in the YBE and $\mathrm{MBE}$ groups. Intact bulls were also placed with cows in the NBE group. A 60-d breeding season was used each of the $3 \mathrm{yr}$ of the study.

Bulls were sterilized by removing a section of the cauda epididymides. This procedure blocks sperm transport without altering penis penetration, libido, or testosterone production. Bulls, 6 to 8 mo of age, were mildly sedated with 10 to $20 \mathrm{mg}$ of xylazine while the scrotal area was surgically prepared. Local anesthesia (lidocaine hydrochloride, $2 \%$ ) was administered to the lower one-third of the scrotum. Each testis was exteriorized and portions of the tail and body of the epididymis were ligated and removed.

Cows that were isolated from bulls were approximately $.8 \mathrm{~km}$ from the pastures that contained bulls. Cows in groups exposed to bulls were separated by a pasture $(.4 \mathrm{~km}$ at closest point) to allow for minimal visual and no fenceline contact with bulls from other treatments.

Blood samples were collected twice weekly via jugular venipuncture from late March until mid-July each year. Blood samples were allowed to clot on ice and stored for $24 \mathrm{~h}$ at $4^{\circ} \mathrm{C}$. Serum was collected from these samples after centrifugation at $1,520 \times \mathrm{g}$ for 15 min and stored at $-20^{\circ} \mathrm{C}$ until it was assayed for progesterone by RLA (Anthony et al., 1981). Intraand interassay CV were $<5$ and $15 \%$, respectively. Concentrations of progesterone in serum were analyzed to determine onset of corpus luteum function and resumption of estrous cycles after calving. The criteria for initiation of estrous cycles were progesterone concentrations in serum of $>1.0 \mathrm{ng} / \mathrm{mL}$ for two consecutive samples followed by cyclical increases and decreases in progesterone indicative of normal luteal function. Cows that did not initiate estrous cycles during the period of blood collection ( 2 to $18 \mathrm{wk}$ postpartum) were assigned the day of the end of the experiment as the day of resumption of estrous cycles. The number of days from parturition to initiation of estrous cycles was calculated for individual cows by subtracting the Julian date of parturition from the Julian date at which the first rise in progesterone was detected.

Effect of treatment on duration of postpartum anestrus was analyzed by ANOVA (Steel and Torrie, 1980) using the GLM procedure of SAS (1985). Presence of bulls, age of bull, parity of cow, and year were the main effects tested in the model. Comparisons of treatment effects were made using orthogonal contrasts. Proportions of cows initiating estrous cycles during the experimental period were analyzed by chisquare analyses (Steel and Torrie, 1980).

\section{Results}

The percentages of cows in which estrous cycles were detected were 92,99 , and $98 \%$ in the NBE, MBE, and YBE treatments, respectively. Primiparous cows had a longer duration of postpartum anestrus than did multiparous cows (range 26 to $29 \mathrm{~d} ; P<.05$; Table 1 ) in each of the treatments. No treatment $\times$ parity interaction was detected $(P>.10$; Table 1$)$ in the response to bull exposure. Therefore, data were pooled

Table 1. Duration of postpartum anestrus within each parity group for cows isolated from bulls and cows exposed to either mature or yearling bulls

\begin{tabular}{lcc}
\hline \hline & \multicolumn{2}{c}{ Days postpartum } \\
\cline { 2 - 3 } Treatments & Multiparous & Primiparous \\
\hline Isolated from bulls & $62^{\text {bd }}$ & $90^{\text {be }}$ \\
Exposed to mature bulls & $49^{\text {cd }}$ & $78^{\text {ee }}$ \\
Exposed to yearling bulls & $52^{\text {cd }}$ & $78^{\text {ce }}$ \\
\hline avalues presented are least squares means; pooled SEM $=2 \mathrm{~d}$. \\
b,cMeans within a column lacking a common superscript letter \\
differ $(P<.05)$ d,e \\
$(P<.05)$.
\end{tabular}




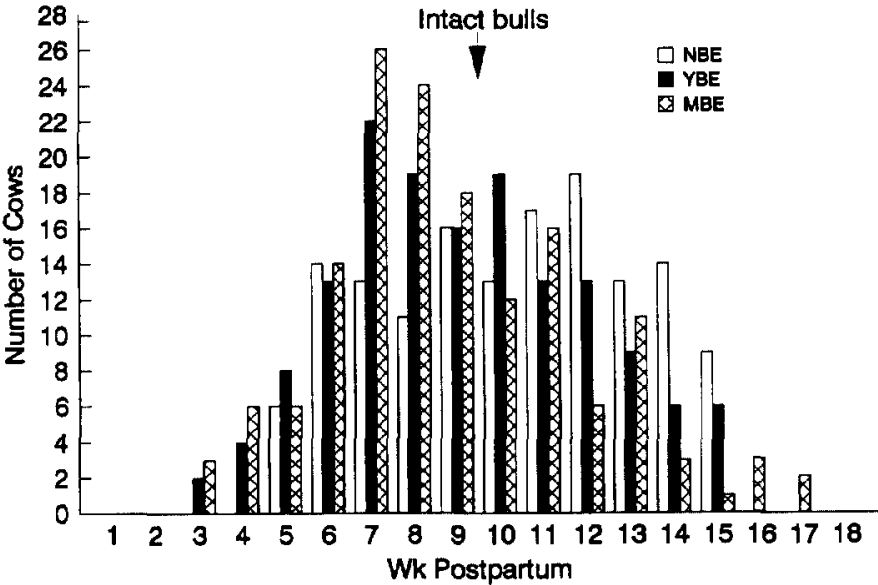

Figure 1. Number of cows initiating estrous cycles by week postpartum for cows isolated from bulls (NBE) and cows exposed to either yearling (YBE) or mature bulls (MBE). Arrow indicates the time of removal of sterile bulls from the YBE and MBE groups and the placement of intact bulls with cows in those groups as well as with cows in the NBE group.

for multi- and primiparous cows within each treatment. This pooled data set had no treatment $\times$ year interaction $(P>.10)$, and postpartum anestrus intervals were pooled within treatments across all $3 \mathrm{yr}$ (Table 2).

Duration of postpartum anestrus for cows in the NBE group $(72.3 \pm 1.7 \mathrm{~d})$ was greater $(P<.01)$ than the duration of postpartum anestrus of cows in either the MBE $(59.5 \pm 1.7 \mathrm{~d})$ or YBE $(61.8 \pm 1.7 \mathrm{~d}$; Table 2$)$ groups. The postpartum anestrus intervals of cows in the MBE and YBE groups did not differ. After wk 9, all cows were exposed to intact bulls. Before the introduction of the intact bulls, the proportion of cows exhibiting estrous cycles in the YBE group did not differ $(P>.50)$ from that in the MBE group (Figure 1).

Because no difference was detected in either duration of postpartum anestrus or pattern of initia- tion of estrous cycles in cows pastured with mature or yearling bulls, data from cows in the YBE and $\mathrm{MBE}$ groups were combined and compared to data of cows in the NBE group. Cows pastured with bulls (combined $\mathrm{MBE}$ and $\mathrm{YBE})$ had a 12 -d shorter $(P<.01)$ interval of anestrus than cows isolated from bulls. The proportion of cows pastured with bulls (combined MBE and YBE) that exhibited estrous cycles before the introduction of intact bulls was higher $(P<.01)$ than that in the NBE group. The effect of bull exposure on the number of cows initiating estrous cycles was observed $(P<.01)$ through wk 15 postpartum.

\section{Discussion}

Yearling and mature bulls had a similar effect on duration of postpartum anestrus of cows in this study. Cows pastured with yearling or mature bulls initiated estrous cycles approximately $12 \mathrm{~d}$ earlier than cows isolated from bulls after calving. These data are consistent with previous research from our laboratory (Zalesky et al., 1984).

Age and stage of development influence the ability of boars to decrease age of onset of puberty in gilts (Kirkwood and Hughes, 1981). The primary mechanism initiating onset of puberty in gilts seems to be the production or release of a pheromone(s) from the boar, which is(are) secreted in saliva from the submandibular salivary gland (Kirkwood et al., 1981; Pearce et al., 1988). Booth (1975) found that the ability to secrete pheromonal $\mathrm{C}_{19}$ steroids was enhanced in boars as they matured. The submandibular gland of the boar matures and is capable of secreting pheromones by 6 mo of age; however, serous cells of these glands undergo hypertrophy between 8 and 10 mo (Booth, 1980; Perry et al., 1980). Therefore, age of the boar affects the ability to produce or release substances necessary for inducing estrous cycles in anestrous gilts.

Pasturing bulls with prepubertal heifers induces onset of puberty earlier than isolating heifers from

Table 2. Duration of postpartum anestrus for cows isolated from bulls and cows exposed to either mature or yearling bulls by year

\begin{tabular}{lcccc}
\hline \hline & \multicolumn{4}{c}{ Days postpartum ${ }^{\mathrm{a}}$} \\
\cline { 2 - 5 } Treatment & 1987 & 1988 & 1989 & Mean \\
\hline Isolated from bulls & 67.7 & 71.8 & 77.2 & $72.3^{\mathrm{b}}$ \\
& $(\mathrm{n}=52)$ & $(\mathrm{n}=51)$ & $(\mathrm{n}=55)$ & $(\mathrm{n}=158)$ \\
Exposed to mature bulls & 60.6 & 52.0 & 65.8 & $59.5^{\mathrm{c}}$ \\
& $(\mathrm{n}=49)$ & $(\mathrm{n}=52)$ & $(\mathrm{n}=53)$ & $(\mathrm{n}=154)$ \\
Exposed to yearling bulls & 55.4 & 60.0 & 69.1 & $61.8^{\mathrm{c}}$ \\
& $(\mathrm{n}=46)$ & $(\mathrm{n}=51)$ & $(\mathrm{n}=55)$ & $(\mathrm{n}=152)$ \\
\hline
\end{tabular}

aValues presented are least squares means; pooled SEM $=1.7 \mathrm{~d}$

b,cMeans within this column lacking a common superseript letter differ $(P<.01)$ 
bulls (Roberson et al., 1991). Izard and Vandenbergh (1982) reported that administration of bull urine during an 8-wk period advanced the onset of puberty in prepubertal heifers. The hastened onset of puberty in these heifers was attributed to a pheromone present in bull urine.

From the results of the present study we reject our initial hypothesis and conclude that if bulls are $>1 \mathrm{yr}$ old, age does not affect the ability of the presence of bulls to shorten the duration of postpartum anestrus in cows. The pattern of initiation of estrous cycles in cows exposed to yearling or mature bulls after calving is similar (Figure 1). Therefore, the cue (whether pheromonal or visual) received by the anestrous cow from either the yearling or mature bull does not seem to be different.

\section{Implications}

The use of biostimulation after parturition shortens the postpartum anestrus interval. Bulls as young as 1 yr of age are as effective as older bulls in shortening the duration of postpartum anestrus. This means that beef producers can use either yearling or mature bulls to reduce the duration of postpartum anestrus. Sterile bull calves could be maintained over the winter, used to reduce postpartum anestrus in the spring, and sold at the beginning of the breeding season. The cost of using young bulls for this purpose would be less than that of maintaining mature, sterile bulls for extended periods of time.

\section{Literature Cited}

Alberio, R. H., G. Schiersmann, N. Carou, and J. Mestre. 1987. Effect of a teaser bull on ovarian and behavioral activity of suckling beef cows. Anim. Reprod. Sci. 14:263.

Anthony, R. V., R. J. Kittok, E. F. Ellington, and M. K. Nielsen. 1981. Effects of zeranol on growth and ease of calf delivery in beef heifers. J. Anim. Sci. 53:1325.
Booth, W. D. 1975. Changes with age in the occurrence of $\mathrm{C}_{19}$ steroids in the testis and submaxillary gland of the boar. J. Reprod. Fertil. 42:459.

Booth, W. D. 1980. A study of some major testicular steroids in the pig in relation to their effect on the development of male characteristics in the prepubertally castrated boar. J. Reprod. Fertil. 59:155.

Burns, P. D., and J. C. Spitzer. 1992. Influence of biostimulation on reproduction in postpartum beef cows. J. Anim. Sci. 70:358.

Custer, E. E., J. G. Berardinelli, R. E. Short, M. Wehrman, and R. Adair. 1990. Postpartum interval to estrus and patterns of $\mathrm{LH}$ and progesterone in first-calf suckled beef cows exposed to mature bulls. J. Anim. Sci. 68:1370.

Gifford, D. R., M. J. D'Occhio, P. H. Sharpe, T. Weatherly, R. Y. Pittar, and D. O. Reeve. 1989. Return to cyclic ovarian activity following parturition in mature cows and first calf heifers exposed to bulls. Anim. Reprod. Sci. 19:209.

Izard, M. K., and J. G. Vandenbergh. 1982. The effects of bull urine on puberty and calving date in crossbred beef heifers. J. Anim. Sci. 55:1160.

Kirkwood, R. N., J. M. Forbes, and P. E. Hughes. 1981. Influence of boar contact on attainment of puberty in gilts after removal of the olfactory bulb. J. Reprod. Fertil. 61:193.

Kirkwood, R. N., and P. E. Hughes. 1981. A note on the influence of boar age on its ability to advance puberty in the gilt. Anim. Prod. 31:211.

Naasz, C. D., and H. L. Miller. 1987. Effects of bull exposure on postpartum interval and reproductive performance in beef cows. J. Anim. Sci. 65(Suppl. 1):426 (Abstr.).

Pearce, G. P., P. E. Hughes, and W. D. Booth. 1988. The involvement of boar submaxillary salivary gland secretions in boar-induced precocious puberty attainment in the gilt. Anim. Reprod. Sci. $16: 81$

Perry, G. C., R. S. Patterson, H. H. MacFie, and C. G. Stinson. 1980. Pig courtship behavior: Pheromonal property of androstene steroids in male submaxillary secretion. Anim. Prod. 31:191.

Roberson, M. S., M. W. Wolfe, T. T. Stumpf, L. A. Werth, A. S. Cupp, N. Kojima, P. L. Wolfe, R. J. Kittok, and J. E. Kinder. 1991. Influence of growth rate and exposure to bulls on age at puberty in beef heifers. J. Anim. Sci. 69:2092.

SAS. 1985. SAS User's Guide: Statistics. SAS Inst. Inc., Cary, NC. Steel, R.G.D., and J. H. Torrie. 1980. Principles and Procedures of Statistics: A Biometrical Approach (2nd Ed.). McGraw-Hill Book Co., New York.

Zalesky, D. D., M. L. Day, M. Garcia-Winder, K. Imakawa, R. J. Kittok, M. J. D'Occhio, and J. E. Kinder. 1984. Influence of exposure to bulls on resumption of estrous cycles following parturition in beef cows. J. Anim. Sci. 59:1135. 